\title{
Online Objective Test Untuk Meningkatkan Layanan Unit Pelaksana Assessment Centre
}

\author{
Febriana S. Marpaung ${ }^{1}$; Tri Hutomo Pamungkas ${ }^{2}$ \\ ${ }^{1,2}$ Unit Pelaksana Assessment Centre, PLN Pusdiklat, Indonesia \\ 11ana.marp03@gmail.com
}

\begin{abstract}
Organizational changes in the PLN environment have an impact on business functions, one of which is the addition of new positions, both structural and functional. This condition influences the increasing number of assessment requests. The refore it is necessary to make an effective service strategy so as to be able to provide fast and accurate services for users of assessment services. Online objective test as a solution to the problem. Analysis was carried out using the SWOT method and Weighted Ranking Decision. This test provides a significant efficiency for PLN in terms of time and cost. In addition, PLN also has exclusive psychological testing material and is protected from copyright infringement, reduces the risk of leakage of test material, and enhances the company's image.
\end{abstract}

Keywords: online objective test, efficiency, service improvement

\begin{abstract}
ABSTRAK
Perubahan organisasi di lingkungan PLN memberi dampak pada fungsi bisnis, salah satunya penambahan jabatan baru, baik struktural maupun fungsional. Kondisi ini berpengaruh terhadap jumlah permintaan asesmen yang semakin meningkat. Oleh karena itu perlu dibuat suatu strategi pelayanan yang efektif sehingga mampu memberikan pelayanan yang cepat dan akurat bagi pengguna jasa asesmen. Online objective test sebagai solusi atas permasalahan tersebut. Analisa dilakukan dengan metode SWOT dan Weighted Ranking Decision. Tes ini memberikan efisiensi yang signifikan bagi PLN yaitu dari sisi waktu dan biaya. Selain itu, PlN juga memiliki materi tes psikologi yang eksklusif dan terhindar dari pelanggaran hak cipta, mengurangi resiko kebocoran materi tes, dan meningkatkan citra perusahaan.
\end{abstract}

Kata kunci: online obective test, efisiensi, peningkatan layanan 


\section{KILAT}

Vol. 9, No. 1, April 2020, P-ISSN 2089-1245, E-ISSN 2655-4925

DOI: https://doi.org/10.33322/kilat.v9i1.781

\section{PENDAHULUAN}

Tantangan terbesar PLN yang sedang dihadapi saat ini adalah proyek 35.000 MW yang merupakan proyek nasional untuk peningkatan perekonomian. Hal ini berdampak pada perubahan organisasi di beberapa unit kerja PLN. Untuk mewujudkannya diperlukan penambahan jumlah tenaga kerja yang kompeten, baik itu soft competency maupun hard competency. Pemilihan tenaga kerja yang tepat wajib dilakukan agar tujuan yang ingin dicapai menjadi efektif dan efisien. Metode yang digunakan Unit Assessment Centre dalam melakukan asesmen terbagi menjadi dua, yaitu metode assessment center dan metode in-class menggunakan tes psikologi (psikotes). Metode assessment center didefinisikan sebagai suatu evaluasi perilaku yang terintegrasi yang menggunakan berbagai teknik evaluasi yang dirancang untuk mengukur kompetensi yang dibutuhkan demi suksesnya dalam jabatan/pekerjaan tertentu. [1] Tes psikologi merupakan salah satu cara untuk mengukur soft competency individu dengan standar psikometri. [2] Aspek yang diukur oleh psikotes dalam konteks PLN adalah kecerdasan, kepribadian dan sikap kerja. Selama ini tes psikologi yang dilakukan oleh PLN berupa paper and pencil test [3] yang membutuhkan durasi waktu selama sepuluh hari kerja untuk menyelesaikannya. Sebagai konsekuensi dari kebijakan HCR korporat, permintaan asesmen di PLN Unit Pelaksana Assessment Centre mengalami peningkatan yang signifikan. Pada tahun 2012, jumlah peserta asesmen adalah berada di angka 9.000 meningkat menjadi lebih dari 31.000 pada tahun 2015. Tahun 2016, data sampai dengan bulan Oktober sudah menunjukkan lebih dari 26.000 peserta. Ilustrasi peserta asesmen dari tahun 2012 hingga 2016 dapat dilihat pada gambar 1.

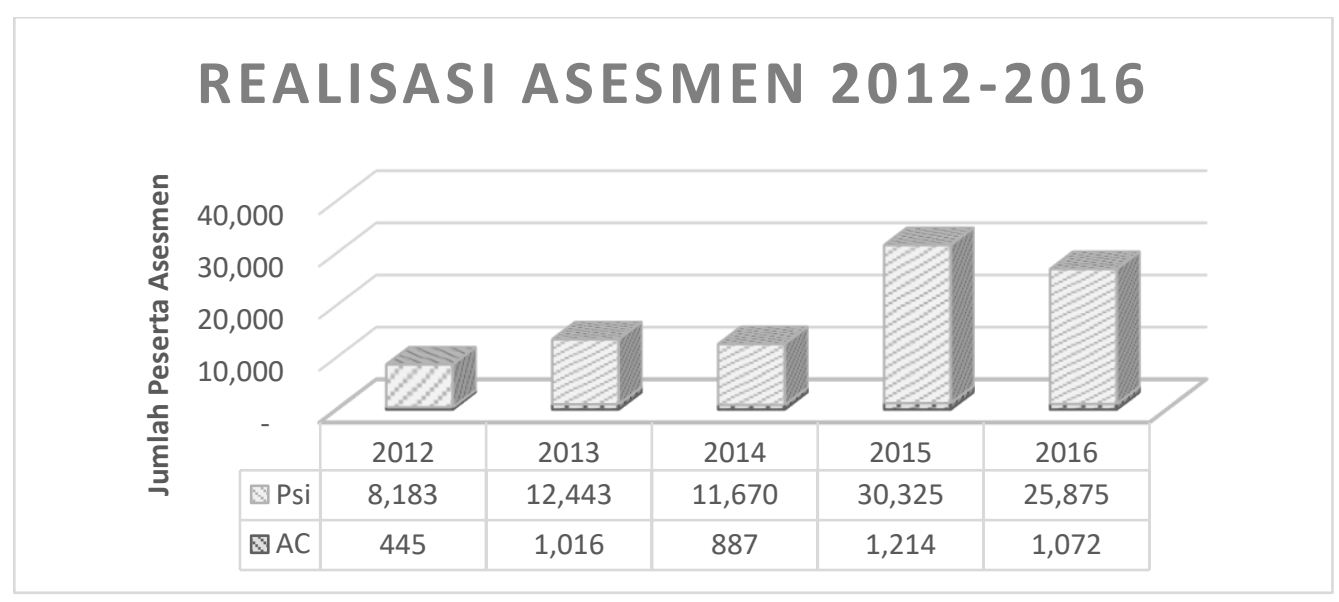

Gambar 1. Jumlah Realisasi Asesmen 2012-2016

Lebih dari 95\% pelaksanaan asesmen di PLN Unit Pelaksana Assessment Centre menggunakan metode asesmen psikologi atau psikotes. Jika data tersebut ditelusuri lebih lanjut, diperoleh fakta bahwa Unit Pelaksana Assessment Centre paling banyak melakukan asesmen psikologi untuk keperluan rekrutmen calon pegawai dibandingkan asesmen pegawai level supervisor. Terutama dalam tiga tahun terakhir di mana asesmen psikologi untuk keperluan rekrutmen mengambil porsi sekitar $75 \%$ dari pelaksanaan asesmen psikologi. Hal ini dapat terlihat pada Gambar 2. 


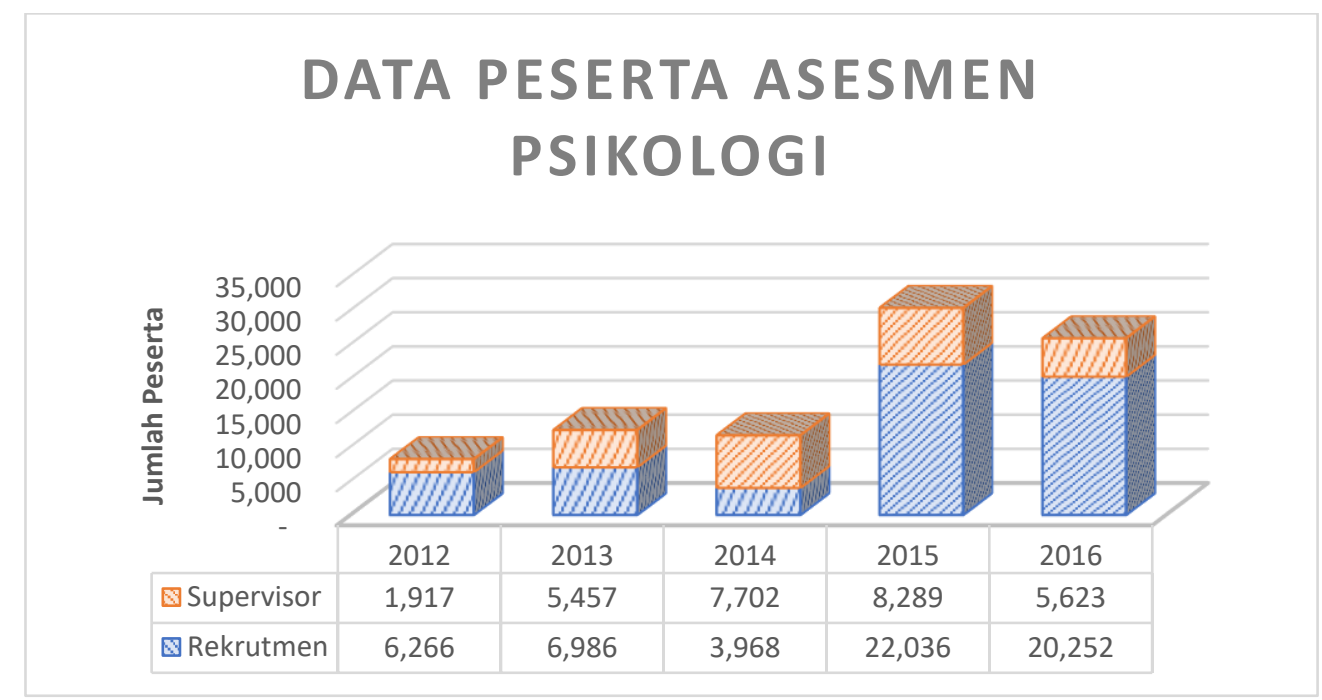

Gambar 2. Data Peserta Asesmen Psikologi.

Jumlah pegawai PLN Assessment Centre saat ini sebanyak 20 (dua puluh) orang untuk melaksanakan asesmen kepada seluruh calon peserta. Menurut analisa beban kerja yang telah dilakukan, untuk melaksanakan asesmen psikologi sejumlah 25.000 orang, diperlukan 10 (sepuluh) orang Psikolog (6). Simulasi beban kerja dapat dilihat pada tabel di bawah ini:

Tabel 1. Analisa Beban Kerja

\begin{tabular}{|l|c|c|c|}
\hline \multicolumn{1}{|c|}{ Methods } & $\begin{array}{c}\text { TMPA } \\
\text { (Days) }\end{array}$ & Participants & $\begin{array}{c}\text { Workload Point } \\
\text { (Days X Participants/ }\end{array}$ \\
\hline Assessment Centre & 16 & 1,000 & 16,000 \\
\hline Psychometric Testing & 10 & 25,000 & 250,000 \\
\hline
\end{tabular}

Jumlah pegawai PLN Assessment Centre yang terbatas mempengaruhi waktu penyelesaian asesmen, biaya, dan layanan kepada pelanggan. Secara makro, kondisi ini berdampak pada pengambilan keputusan di tingkat pengguna jasa Unit Pelaksana Assessment Centre, baik itu unit bisnis PLN maupun PLN Kantor Pusat. Pengambilan keputusan dapat terkendala karena data hasil asesmen yang dijadikan dasar pengambilan keputusan belum tersedia.

Untuk mengatasi permasalahan ini, dilakukan focus discussion group, analisa SWOT, dan weighted ranking decision untuk mencari alternative solusi yang efektif dan efisien. Solusi yang dianggap paling efektif adalah pengembangan online objective test yang dapat memberikan efisiensi dalamm beberapa aspek. Hasil yang diharapkan dari implementasi program tersebut adalah tercapainya kondisi ideal dalam tes psikologi di Unit Pelaksana Assessment Centre. Kondisi ideal tersebut adalah penggunaan tes modern yang berbasis komputer (computer based). Materi tes yang digunakan mengandalkan materi tes objektif sehingga diperoleh validitas dan akurasi tes yang lebih baik secara signifikan. Keterlibatan evaluator dalam proses pelaporan minimal karena psikolog evaluator hanya akan merancang written feedback satu kali dan terkomputerisasi. Materi tes yang digunakan juga harus milik sendiri agar terbebas dari kemungkinan terjadinya permasalahan hak cipta. Manfaat bagi unit operasional pengguna jasa Unit Pelaksana Assessment Centre adalah akan mendapat hasil tes psikologi yang lebih cepat yaitu satu hari dan dengan data yang lebih valid. 


\section{KILAT}

Vol. 9, No. 1, April 2020, P-ISSN 2089-1245, E-ISSN 2655-4925

DOI: https://doi.org/10.33322/kilat.v9i1.781

\section{METODOLOGI}

Metode dan perangkat analisa yang digunakan yaitu:

a. Diagnose yaitu tahap analisa permasalahan (identifikasi gap). Perangkat analisa yang digunakan dalam tahap diagnose adalah:

- Focused Group Discussion (FGD)

FGD adalah proses pengumpulan informasi mengenai suatu masalah tertentu yang sangat spesifik melalui diskusi kelompok (7). FGD dilakukan untuk mengeksplorasi hasil dari mind mapping yang telah dibuat. FDG dilakukan bersamaan dengan weekly meeting Bidang PMPD dan dihadiri oleh seluruh Supervisor dan Staf di Bidang Pengembangan Materi dan Pengolahan Data.

Solusi-solusi tersebut dikelompokkan ke dalam dua kategori yaitu yang controllable dan yang uncontrollable. Selanjutnya, solusi yang controllable akan dikembangkan menjadi alterlatif solusi. Sedangkan yang uncontrollable tidak akan disusulkan menjadi project assignment.

Tabel di bawah merupakan ringkasan dari hasil FGD.

Tabel 2. Hasil FGD

\begin{tabular}{|c|l|l|c|}
\hline NO & \multicolumn{1}{|c|}{ PERMASALAHAN } & \multicolumn{1}{|c|}{ SOLUSI } & CONTROLLABLE \\
\hline 1 & Overload peserta tes psikologi. & Pengurangan/pembatasan peserta tes psikologi. & Tidak \\
\hline 2 & \multirow{2}{*}{ Kekurangan psikolog evaluator. } & Penambahan SDM Profesi Psikolog. & Tidak \\
\cline { 4 - 4 } & & Optimalisasi psikolog eksternal. & Ya \\
\hline 4 & \multirow{2}{*}{ Materi tes psikologi } & Pengembangan tes objektif berbasis komputer. & Ya \\
\cline { 3 - 4 } & & Pembelian materi tes baru. & $Y a$ \\
\cline { 3 - 4 } & & Menggunakan asesmen online pihak ketiga. & Ya \\
\hline
\end{tabular}

\section{- Analisa SWOT}

Analisa SWOT adalah metode analisa terstruktur yang digunakan untuk evaluasi kekuatan (strength), kelemahan (weakness), kesempatan (opportunities) dan ancaman (threat) yang terdapat dalam sebuah organisasi. Terdapat 2 (dua) aspek yang harus dilihat yaitu fokus di dalam organisasi - internal (strength \& weakness) dan fokus ke luar organisasi - eksternal (opportunity \& threat). Analisa SWOT digunakan untuk mengenali kondisi organisasi dan membuat strategi yang paling tepat untuk mencapai sasaran organisasi di masa mendatang. 
Tabel 3. SWOT Matrix

\begin{tabular}{|c|c|c|}
\hline SW & $\begin{array}{l}\text { STRENGTH } \\
\text { - PMPD. } \\
\text { - SDM Psikologi. } \\
\text { - Pegawai IT. } \\
\text { - TAP. }\end{array}$ & $\begin{array}{l}\text { WEAKNESS } \\
\text { - Paper-and-pencil test. } \\
\text { - } \text { Tes proyektif. } \\
\text { - Psikolog evaluator terbatas. } \\
\text { - Materi tes umum. } \\
\text { - Komptensi pengembangan materi tes } \\
\text { psikologi. }\end{array}$ \\
\hline $\begin{array}{l}\text { OPORTUNITY } \\
\text { - Psikotes berbasis komputer. } \\
\text { - Psikolog associate. } \\
\text { - } \text { Menjadi anak perusahaan. } \\
\text { - HIMPSI. } \\
\text { - } \text { Kerjasama dengan kampus. } \\
\text { - } \text { Asesmen instansi lain. }\end{array}$ & $\begin{array}{l}\text { SO } \\
\text { - Pengembangan TAP pada aspek } \\
\text { kepribadian. }\end{array}$ & $\begin{array}{l}\text { WO } \\
\text { - Kerjasama pengembangan materi } \\
\text { dengan universitas. } \\
\text { - Optimalisasi evaluator eksternal. }\end{array}$ \\
\hline $\begin{array}{l}\text { THREAT } \\
\text { - Keraguan terhadap hasil asesmen. } \\
\text { - Vendor tes psikologi pihak ketiga. }\end{array}$ & $\begin{array}{l}\text { ST } \\
\text { - Pengembangan tes modern berbasis } \\
\text { komputer. }\end{array}$ & $\begin{array}{l}\text { WT } \\
\text { - Pelaksanaan tes psikologi berbasis } \\
\text { komputer oleh penyedia jasa pihak } \\
\text { ketiga. } \\
\text { - Pengembangan tes objektif. }\end{array}$ \\
\hline
\end{tabular}

b. Design

- Weighted Ranking Decision

Tahapan yang telah dilaksanakan memunculkan beberapa alternatif solusi dan program strategis yang dapat dilakukan untuk mengatasi permasalahan yang terjadi seputar tes psikologi. Berdasarkan analisa SWOT maupun hasil FGD, dapat dirangkum dalam alternatif solusi sebagai berikut:

1. Optimalisasi psikolog evaluator eksternal.

2. Pengembangan online objective test.

3. Pelaksanaan tes psikologi berbasis komputer oleh pihak ketiga.

Dari ketiga alternatif tersebut, dilakukan proses pembobotan sebagaimana berikut:

Tabel 4. Pembobotan Kriteria

\begin{tabular}{|l|c|c|c|c|c|c|c|}
\hline & Man & Material & Method & Machine & Money & $\Sigma$ & Bobot \\
\hline Man & $\mathrm{x}$ & 0 & 1 & 0 & 0 & 1 & $10 \%$ \\
\hline Material & 1 & $\mathrm{x}$ & 1 & 0 & 1 & 3 & $30 \%$ \\
\hline Method & 1 & 1 & $\mathrm{x}$ & 1 & 0 & 3 & $30 \%$ \\
\hline Machine & 0 & 0 & 0 & $\mathrm{x}$ & 1 & 1 & $10 \%$ \\
\hline Money & 1 & 0 & 0 & 1 & $\mathrm{x}$ & 2 & $20 \%$ \\
\hline \multicolumn{7}{|c|}{ Total } \\
\hline
\end{tabular}

Keterangan kriteria:

0 : tidak penting

1 : penting 
Setelah diketahui bobot masing-masing kriteria, dilakukan penilaian secara kuantitatif terhadap masing-masing alternatif yang telah diusulkan. Hasil dari penilaian kuantitatif terhadap beberapa alternatif tersebut adalah sebagai berikut:

Tabel 5. Hasil Weighted Ranking Decision

\begin{tabular}{|c|c|c|c|c|c|c|c|}
\hline $\begin{array}{c}\text { Faktor } \\
\text { Keputusan }\end{array}$ & Bobot & Alt 1 & Alt 2 & Alt 3 & $\%$ Alt 1 & $\%$ Alt 2 & $\%$ Alt 3 \\
\hline Man & $10 \%$ & 3 & 3 & 2 & $6 \%$ & $6 \%$ & $4 \%$ \\
\hline Material & $30 \%$ & 2 & 3 & 4 & $12 \%$ & $18 \%$ & $24 \%$ \\
\hline Method & $30 \%$ & 2 & 4 & 4 & $12 \%$ & $24 \%$ & $24 \%$ \\
\hline Machine & $10 \%$ & 2 & 3 & 3 & $4 \%$ & $6 \%$ & $6 \%$ \\
\hline Money & $20 \%$ & 2 & 4 & 1 & $8 \%$ & $16 \%$ & $4 \%$ \\
\hline \multicolumn{5}{|c|}{ Total Prosentase Alternatif } & $42 \%$ & $70 \%$ & $62 \%$ \\
\hline
\end{tabular}

Keterangan skala:
1: buruk
3: cukup
5: baik sekali
2: kurang
4: baik

Dari hasil Weighted Ranking Decision tersebut diperoleh bahwa alternatif solusi nomor 2 yaitu pengembangan tes objektif berbasis komputer, merupakan alternatif yang memiliki nilai paling tinggi. Dengan demikian, disimpulkan bahwa solusi yang akan ditindaklanjuti adalah pengembangan test berbasis komputer (online). Hal ini sekaligus juga mengembangkan sistem TAP (Tes Adaptif PLN) yang telah dimiliki Unit Pelaksana Assessment Centre dengan menambahkan materi tes kepribadian dan sikap kerja.

- Kajian Kelayakan Finansial (KKF)

Kajian kelayakan finansial dilakukan dengan dua skenario. Skenario pertama adalah membandingkan biaya tes psikologi sebelum implementasi program dan setelah implementasi program. Skenario kedua adalah membandingkan opsi solusi yang tersedia yaitu mengembangkan tes sendiri atau melakukan tes psikologi online melalui penyedia jasa pihak ketiga. Biaya yang dibandingkan adalah yang bersifat variable cost, sedangkan fixed cost dan overhead cost tidak dibandingkan di sini karena diasumsikan sama.

1. Perbandingan biaya sebelum dan setelah implementasi program.

Tabel 6. Perbandingan Biaya Per Orang

\begin{tabular}{|c|l|r|r|}
\hline NO & \multicolumn{1}{|c|}{ ITEM } & SEBELUM IMPLEMENTASI & SESUDAH IMPLEMENTASI \\
\hline 1 & Biaya Pengembangan Materi & $\mathrm{Rp5,000}$ & $\mathrm{Rp} 10,000$ \\
\hline 2 & Alat tulis kantor & $\mathrm{Rp5}, 000$ & $\mathrm{Rp0}$ \\
\hline 3 & Cetak materi & $\mathrm{Rp27,000}$ & $\mathrm{Rp0}$ \\
\hline 4 & Sewa laptop dan jaringan & $\mathrm{Rp0}$ & $\mathrm{Rp50,000}$ \\
\hline 5 & Biaya maintenance materi & $\mathrm{Rp0}$ & $\mathrm{Rp5}, 000$ \\
\hline 6 & Honorarium skoring & $\mathrm{Rp50,000}$ & $\mathrm{Rp0}$ \\
\hline 7 & Honorarium evaluator & $\mathrm{Rp92,000}$ & $\mathrm{Rp0}$ \\
\hline & TOTAL & & $\mathrm{Rp65,000}$ \\
\hline
\end{tabular}


Berdasarkan tabel 6, diketahui bahwa biaya tes psikologi dengan paper-and-pencil testadalah Rp.92.000,- sedangkan jika program telah diimplementasikan biaya per peserta adalah Rp.65.000,-. Jika dikali 25.000 peserta tes per tahun maka biaya variabel sebelum implementasi adalah Rp. 2.300.000.000,- sedangkan setelah implementasi adalah Rp.1.625.000.000,-. Terjadi penghematan biaya variabel sebesar Rp.675.000.000,-.

Selain biaya variabel, potensi efesiensi biaya dapat diperoleh sebagai akibat dari penghematan man power. Jika diasumsikan setiap pegawai mendapat penugasan 2 kali kegiatan per bulan, maka diperoleh penghematan man power per tahun sebagaimana tabel 7.

Tabel 7. Penghematan Biaya Man Power

\begin{tabular}{|c|l|c|c|c|c|c|r|}
\hline NO & Man Power & Peran & Jumlah & Hari & Kali & Biaya Pegawai & Penghematan \\
\hline 1 & Psikolog & Evaluator & 2 & 5 & 2 & Rp180,000,000 & Rp120,000,000 \\
\hline 2 & Sarjana Psikologi & Scorer & 12 & 3 & 2 & Rp96,000,000 & Rp230,400,000 \\
\hline \multicolumn{6}{|c|}{ TOTAL ESTIMASI PENGHEMATAN } & Rp350,400,000 \\
\hline
\end{tabular}

Berdasarkan analisa di atas, dapat disimpulkan bahwa implementasi program unggulan akan menghasilkan penghematan Rp.725.400.000,- per tahun.

2. Perbandingan mengembangkan sendiri dan melalui pihak ketiga.

Perubahan operasional tes psikologi dari paper-and-pencil test menjadi computer based adalah suatu strategi bagi PLN Unit Pelaksana Assessment Centre. Terdapat dua pilihan tindak lanjut yaitu mengembangkan sendiri atau dikembangkan oleh pihak ketiga. Informasi biaya tes psikologi oleh pihak ketiga diperoleh dari pihak ketiga melalui website atau media promosi mereka. Perbandingan didasarkan pada beberapa asumsi. Pertama adalah biaya yang dihitung hanya yang bersifat biaya variabel. Biaya variabel tes melalui vendor adalah tarif tes per orang sesuai harga vendor. Sedangkan biaya variabel tes psikologi melalui TAP yang dikembangkan sendiri adalah biaya pembuatan materi, biaya pemeliharaan sistem dan biaya pembuatan sistem. Hasil perbandingan dapat dilihat pada tabel 8 dan 9 serta gambar 3 .

Tabel 8. Perbandingan Biaya Satuan Vendor

\begin{tabular}{|l|c|c|r|r|r|}
\hline \multicolumn{1}{|c|}{ ASPEK } & Jumlah & Satuan & TAP & Vendor A & \multicolumn{1}{c|}{ Vendor B } \\
\hline Pembuatan sistem & $\mathbf{1}$ & kali & Rp300,000,000 & Rp0 & Rp0 \\
\hline Pembuatan materi & $\mathbf{3}$ & buah & Rp250,000,000 & Rp0 & Rp0 \\
\hline Pemeliharaan sistem & $\mathbf{1}$ & kali & Rp1,000,000,000 & Rp0 & Rp0 \\
\hline Biaya jasa tes & $\mathbf{2 5 , 0 0 0}$ & orang & Rp0 & Rp700,000 & Rp1,100,000 \\
\hline
\end{tabular}




\section{KILAT}

Vol. 9, No. 1, April 2020, P-ISSN 2089-1245, E-ISSN 2655-4925

DOI: https://doi.org/10.33322/kilat.v9i1.781

Tabel 9. Perbandingan Total Biaya Vendor

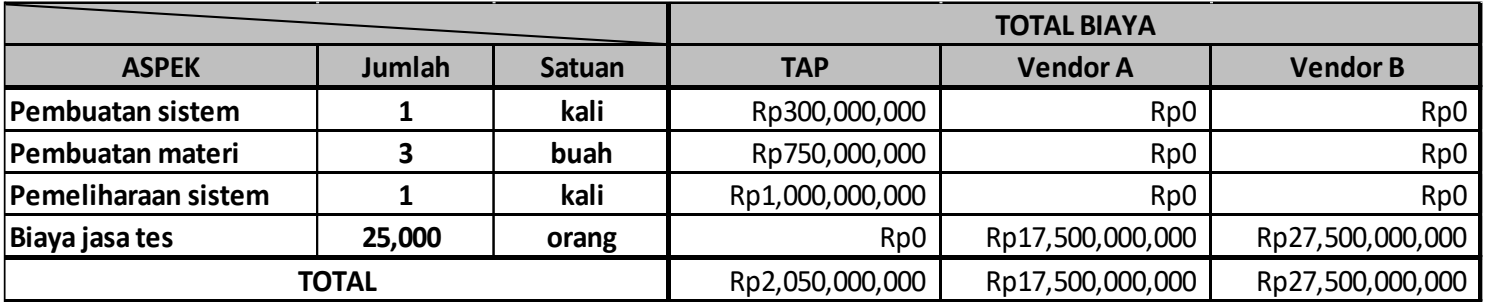

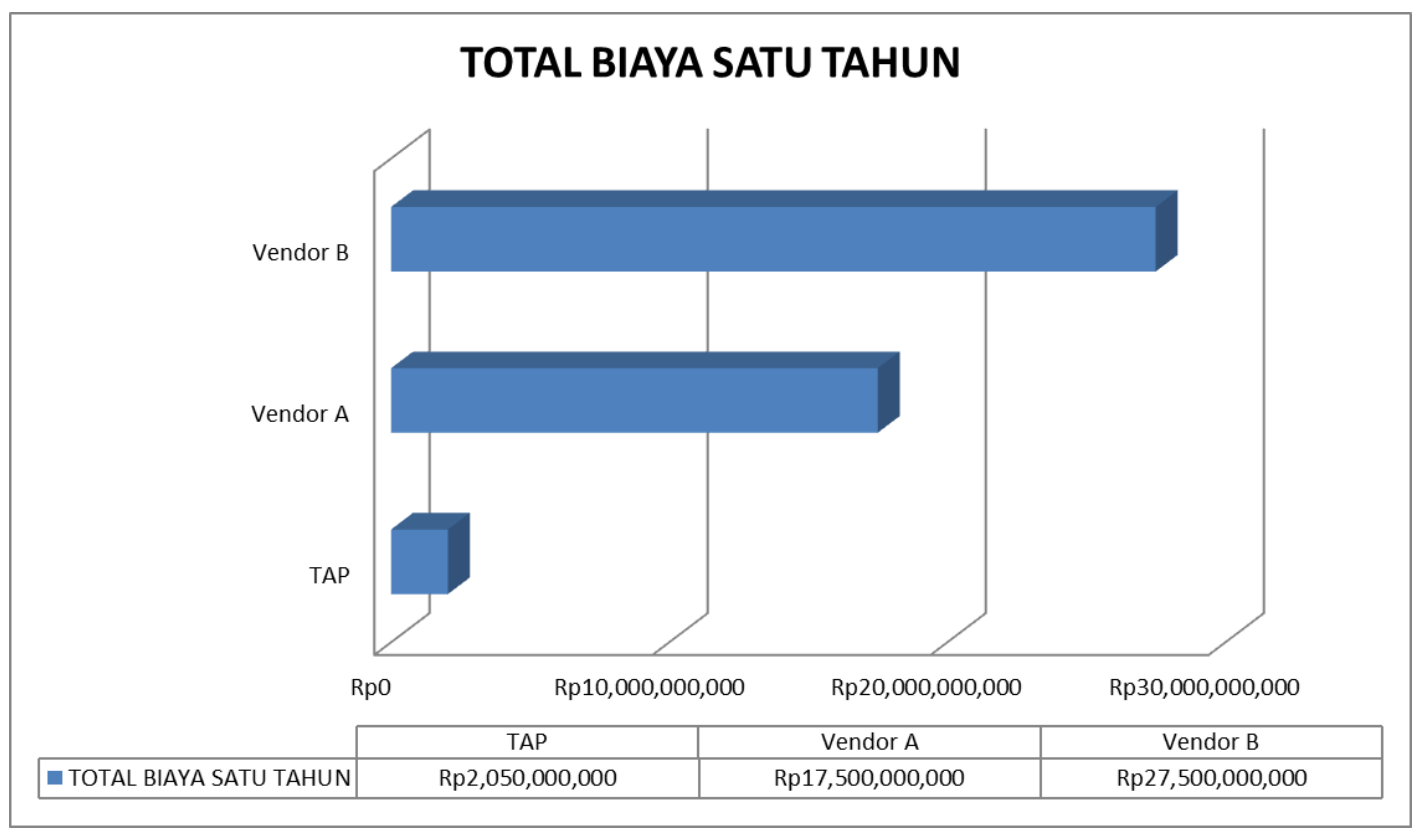

Gambar 3. Perbandingan Total Biaya Satu Tahun

\section{HASIL}

Hasil dari implementasi online objective test bagi PLN adalah meningkatnya efisiensi waktu dan biaya pelaksanaan tes psikologi, yaitu:

1. Efisiensi waktu yang semula 10 (sepuluh) hari menjadi 1 (satu) hari

2. Efisiensi biaya:

- Efisiensi biaya akibat dari efisiensi waktu sebesar Rp.350.400.000, per tahun. Diperoleh dari asumsi penghematan penggunaan sumber daya manusia (manpower) yang dikonversi ke dalam bentuk rupiah.

- Efisiensi biaya akibat perubahan operasional dari paper-and-pencil test menjadi computerbased test sebesar Rp.675.000.000, per tahun.

- Efisiensi biaya jika membandingkan pelaksanaan tes psikologi online dengan pihak ketiga sebesar Rp.15.450.000.000, sampai 25.450.000.000, per tahun.

\section{KESIMPULAN}

Kesimpulan yang dapat diperoleh:

1. Implementasi online objective test meningkatkan efisiensi bagi PLN yang berupa efisiensi waktu dan biaya, sehingga dapat meningkatkan layanan Unit Pelaksana Assessment Centre kepada pelanggan.

2. Pengembangan online objective test merupakan solusi ideal untuk meningkatkan layanan Unit Pelaksana Assessment Centre. 
3. Pengembangan online objective test memberi dampak tangible yang berupa pengurangan risiko kebocoran soal, kepemilikan materi tes yang eksklusif, terhindar dari risiko pelanggaran hak cipta, mendapatkan kualitas data yang lebih valid.

Saran yang dapat diberikan:

1. Melakukan pengembangan secara berkelanjutan terhadap materi tes psikologi objektif.

2. Meningkatkan infrastruktur penunjang tes online seperti keandalan jaringan, penyediaan server dan perbaikan hardware.

\section{DAFTAR PUSTAKA}

[1] D. E. Rupp, "Guidelines and ethical considerations for assessment center operations," Int. J. Sel. Assess., vol. 17, no. 3, pp. 243-253, 2009.

[2] A. Anastasi, "Psychological testing / Anne Anastasi, Susana Urbina.," 1997.

[3] A. Supratiknya, Pengukuran Psikologis. 2014. 